\title{
Belis: Tradisi Perkawinan Masyarakat Insana Kabupaten Timor Tengah Utara (Kajian Historis dan Budaya Tahun 2000-2017)
}

\author{
Fransiska Idaroyani Neonnub ${ }^{1}$, Novi Triana Habsari ${ }^{2}$ \\ ${ }^{1}$ Alumni Mahasiswa Program Studi Pendidikan Sejarah FKIP Universitas PGRI Madiun \\ ${ }^{2}$ Dosen Program Studi Pendidikan Sejarah FKIP Universitas PGRI Madiun
}

\begin{abstract}
Abstrak
Penelitian ini bertujuan untuk mengetahui sejarah, nilai dan makna pergeseran "belis" dalam tujuh belas tahun terakhir pada tradisi perkawinan di masyarakat Insana Kabupaten Timor Tengah Utara. Penelitian dilakukan di Kecamatan Insana Kabupaten Timor Tengah Utara Propinsi Nusa Tenggara Timur (NTT).

Penelitian dilakukan selama lima bulan antara bulan Februari sampai Juli 2017. Adapun bentuk pendekatan penelitian ini adalah pendekatan kualitatif; yaitu penelitian yang menyelidiki suatu fenomena sosial dan masalah manusia. Jenis penelitian ialah penelitian deskriptif. Sumber data yang digunakan adalah sumber data primer dan sekunder. Pengumpulan data menggunakan observasi, wawancara dan dokumentasi.

Hasil penelitianmenunjukkan bahwa "Belis" merupakan tradisi dalam perkawinan adat masyarakat Insana, "belis" merupakan tradisi yang telah ditinggalkan dan diadopsi oleh masyarakat Insana. Dalam perkawinan adat masyarakat Insana, "belis" selalu mempunyai tempatnya tersendiri sebab berbicara soal perkawinan berarti berbicara soal "belis". Sejarah adanya "belis" dalam tradisi perkawinan adat masyarakat Insana adalah suatu peninggalan kebudayaan dari leluhur yang diadopsi dari kehidupan para raja atau bangsawan. Nilai yang terkandung dalam "belis", yakni nilai historis dan nilai budaya. Nilai sejarah karena "belis" merupakan suatu peninggalan tradisi dari zaman nenek moyang masyarakat Insana dan mempunyai nilai adat-istiadat, sedangkan nilai budaya karena "belis" itu selalu dan terus-menerus dilakukan dalam tradisi perkawinan masyarakat Insana, "belis" hidup dan berkembang dalam kehidupan masyarakat Insana. Pergeseran makna belis dalam tujuh belas tahun terakhir dapat ditinjau dari beberapa aspek yakni ekonomi, tinggi rendahnya pendidikan dari mempelai wanita dan juga adanya kebiasaan meniru dari suku lain.
\end{abstract}

Kata Kunci: belis, tradisi perkawinan, historis, budaya

\section{Pendahuluan}

Negara Kesatuan Republik Indonesia (NKRI) merupakan negara yang dikenal sebagai negara kepulauandengan dilengkapi dengan beragam kebudayaan, suku, ras, adat-istiadat dan tradisi yang berbeda pada tiap masyarakatnya yang ada. Perbedaan antara pulau yang satu dengan lainnya seolah-olah menawarkan keindahan yang tak tergantikan oleh negara-negara lainnya. Hal itu dapat ditemukan dalam kehidupan masyarakat daerah yang mempunyai kebiasaan atau tradisi dalam konteks perayaan sebuah acaradari yang bersifat sakral (suci) sampai pada sekedar berbagi kebahagiaan bersama handai taulan. Indonesia yang kaya akan perbedaan terus menawarkan nilai pembeda antar kumpulan etnis yang ada.

Berkembangnya ilmu pengetahuan dan teknologi di era saat ini semakin mengurangi makna dan nilai dari kesakralan suatu tradisi yang dimiliki masyarakat adat. Segalanya telah berubah 
dari yang bersifat suci menjadi sesuatu yang instan dan konsumtif mengikuti tren perkembangan zaman yang ada.Hilangnya makna dan nilai dari perayaan acara perkawinan bagi setiap daerah menjadi persoalan bersama bagi setiap generasi pemilik tradisi adat. Hal tersebut dapat kita jumpai pada kehidupan masyarakat adat propinsi Nusa Tenggara Timur (NTT) secaramenyeluruh dan khususnya Kabupaten Timor Tengah Utara pada masyarakat adat Insana.

Masyarakat merupakan sejumlah manusia dalam arti seluas-luasnya dan terikat oleh suatu kebudayaan yang mereka anggap sama (Kamus Besar Bahasa Indonesia). Masyarakat Insana adalah masyarakat yang masih asli susunannya, khususnya bila dibandingkan dengan kerajaan-kerajaan lain di Timor yang telah banyak mengalami perubahaan semenjak pembentukan Desa Gaya Baru pada era 1960-an. Masyarakatnya tersusun dalam suatu struktur adat berjenjang, yang terdiri dari raja-raja, suku-suku, serta rakyat biasa.

Adat-istiadat dan ritus Insana juga masih terpelihara dengan baik, misalnya upacara pengumpulan upeti, upacara kematian raja-raja, upacara potong rambut bayi, upacara rumah adat, upacara bercocok tanam, dan upacara perkawinan (Usfinit, 2003). Lagi-lagi sejatinya aturan adat tidak lagi tampil sebagai sesuatu yang pasti dan permanen namun masyarakat pelaku adat mulai merusaknnya dengan mencampurkan urusan adat dengan persoalan ekonomi. Salah satunya adalah dalam hal perkawinan dalam masyarakat Insana, yang sering dikaitkan dengan pemberian "belis" (maskawin atau mahar).

Usfinit dalam bukunya "MaubesInsana" menyatakan: "Belis" merupakan unsur penting dalam perkawinan dan harus dilaksanakan oleh pihak laki-laki supaya bisa membawa permpuan ke rumah adat sukunya (naseb nono) dan supaya anakanaknya nanti berhak memakai nama sukunya."Belis" tidak untuk disatukan dengan perkawinan yang besifat sakral secara agama akan tetapi urusan selalu berdampingan ketika sesorang akan melakukan hajatan perkawinan.

Dipisahkan adat masih sangat mendominasi terutama dalam proses perkawinan. Salah satunya ialah dalam proses pemberian "belis". Selain dipandang sebagai tradisi yang memiliki nilai-nilai luhur dan bentuk penghargaan terhadap perempuan, namun di satu sisi juga sebagai pengikat pertalian kekeluargaan dan simbol untuk mempersatukan laki-laki dan perempuan sebagai suami istri. "Belis" juga dianggap sebagai syarat utama pengesahan berpindahnya suku perempuan ke suku suami atau mengikuti suku suami.

Di Nusa Tenggara Timur ada beragam "belis" yang digunakan umunya berupa emas, perak, uang dan hewa seperti kerbau, kuda. Di daerah lainnya di Nusa Tenggara Timur, seperti di Alor, "belis" 
berupa mokko (nakara kecil) di Flores Timur dan Maumere berupa berupa gading gajah. "Belis" pada masyarakat Insana, kononnya dibedakan dalam bentuk keturunan bangsawan atau tidak. Jika perempuan merupakan anak dari kaum bangsawan maka nilai "belis" atau mas kawinnya berbeda dan tentu lebih mahal dari yang bukan keturunan bangsawan.

Seiring berkembangnya zaman, di mana seorang perempuan sudah tidak dibatasi lagi dalam hal pendidikan dan persamaan gender, maka tingkat pendidikan perempuan juga terkadang menjadi penentu tinggi-rendahnya "belis" yang harus di bawa oleh laki-laki. Adanya campuran antara urusan adat dan ekonomi, ditambah adanya sedikit pergeseran makna dari "belis" yang sudah bergeser dari tahun ketahun dan meninggalkan nilai historis dan budaya dari "belis" tersebut, maka menarik untuk dikaji secara mendalam.

\section{Tinjauan Pustaka}

\section{A. Tradisi Perkawinan}

\section{Pengertian Tradisi}

Tradisi dalam Bahasa Latin traditio yang artinya "diteruskan" atau kebiasaan, dalam pengertian yang paling sederhana adalah suatu yang telah dilakukan untuk sejak lama dan menjadi bagian dari bagian suatu kelompok masyarakat, biasanya drai suatu Negara, kebudayaan, waktu, atau agama yang sama. Hal yang paling mendasar dari tradisi adalah adanya informasi yang diteruskan dari generasi ke generasi baik tertulis maupun lisan, karena tanpa adanya ini, suatu tradisi dapat punah. Rendra dalam bukunya "Mempertimbangkan Tradisi" menyatakan: Tradisi adalah kebiasaan yang turun-temurun dalam masyarakat. Ia merupakan kesadaran kolektif sebuah masyarakat. Sifatnya luas sekali, meliputi segala segala kompleks kehidupan sehingga sulit disisihkan dengan perincian yang tepat dan pasti.

Terutama sulit sekali diperlakukan serupa karena tradisi itu bukan objek yang mati, melainkan alat yang hidup untuk melayani manusia yang hidup pula. Ia bisa disederhanakan, tetapi kenyataan tidak sederhana. Tradisi merupakan sinonim dari kata "budaya" yang keduanya merupakan hasil karya. Tradisi adalah hasil karya masyarakat, begitupun dengan budaya. Keduanya saling mempengaruhi. Kedua kata ini merupakan personafikasi dari sebuah makna hukum tidak tertulis, dan hukum tak tertulis ini menjadi patokan norma dalam masyarakat yang dianggap benar.

Menurut Hasan Hanafi, tradisi (turats) adalah segala warisan masa lampau (baca tradisi) yang sampai kepada kita dan masuk dalam kebudayaan yang sekarang berlaku. Dengan demikian, bagi Hanafi, tradisi tidak hanya merupakan persoalan meninggalkan sejarah, tetapi sekaligus merupakan persoalan kontribusi zaman kini dalam berbagai tingkatannya. Secara terminologi, perkataan tradisi mengandung suatu pengertian tersembunyi tentang 
adanya kaitan antara masa lalu dengan masa kini. Merujuk pada sesuatu yang diwariskan oleh zaman dahulu tetapi masih berwujud dan berfungsi masa sekarang. Ketika orang berbicara tentang tradisi Islam atau tradisi Kristen secara tidak langsung mereka sedang menyebutkan serangkaian ajaran atau doktrin yang dikembangkan ratusan atau ribuan tahun lalu. Tetapi masih dan malah tetap berfungsi sebagai pedoman dari kehidupan sosial pada masa kini.

Ajaran Islam atau Kristen tersebut masih berfungsi hingga saat ini, karena adanya proses pewarisan sejak awal berdirinya ajaran tersebut, melewati berbagai kurun generasi dan diterima oleh generasi kini. Oleh karena itu, tradisi dalam pengertian yang paling elementer adalah sesuatu yang ditransmisikan atau diwariskan dari masal lalu ke masa ini.

Secara pasti, tradisi lahir bersama dengan kemunculan manusia dimuka bumi. Tradisi berevolusi menjadi budaya. Itulah sebab sehingga keduanya merupakan personifikasi. Budaya adalah cara hidup yang dipatuhi oleh anggota masyarakat atas dasar kesepakatan bersama. Dari sini, penulis memahami "belis" dan dipertahankan hingga saat ini, sehingga penulis merasa perlu memaparkan tentang defenisi tradisi tertentu.

\section{Pengertian Perkawinan}

Perkawinan adalah ikatan lahir batin antara seorang pria dengan seorang wanita sebagai suami istri dengan tujuan membentuk keluarga (rumah tangga) yang bahagia dan kekal berdasarkan Ketuhanan Yang Maha Esa (UU nomor 1 tahun 1974).Perkawinan merupakan ikatan lahir batin dan persatuan antara dua pribadi yang berasal dari keluarga, sifat, kebiasaan dan budaya yang berbeda.

Perkawinan juga membutuhkan penyesuaian secara terus-menerus. Setiap perkawinan, selain cinta juga diperlukan saling pengertian yang mendalam, kesediaan untuk slaing menerima pasangan masing-masing dengan latar belakang yang merupakan bagian dari kepribadiannya. Hal ini berarti mereka harus bersedia menerima dan memasuki lingkungan sosial budaya pasangannya, dan karenanya dibutuhkan keterbukaan dan toleransi yang sangat tinggi serta penyesuaan diri yang harmonis Wismanto (dalam Suryanto, 2006).

Perkawinan adalah ikatan sosial atau ikatan perjanjian hukum antar pribadi yang membentuk hubungan kekerabatan dan yang merupakan suatu pranata dalam budaya setempat yang meresmikan hubungan antar pribadi yang biasanya intim dan seksual. Perkawinan umumnya dimulai dan diresmikan dengan upacara pernikahan. Pada dasarnya, perkawinan dijalani dengan maksud untuk membentuk keluarga.

Menurut Soemiyati

perkawinan dalam istilah agama disebut "nikah" ialah melakukan sebuah aqad atau perjanjian untuk mengikatkan diri antara seorang laki-laki dan wanita untuk 
menghalalkan hubungan kelamin antara kedua belah pihak untuk mewujudkan suatu kebahagian hidup berkeluarga yang diliputi rasa kasih sayang dan ketentraman yang diridhai Allah.

\section{Pengertian Tradisi Perkawinan}

Tradisi perkawinan adalah segala sesuatu yang berkaitan dengan perkawinan entah berupa upacara, adat-istiadat yang telah menjadikebiasaan yang telah ada sejak lama, diwariskan dan masih dilakukan hingga saat ini. Pada msyarakat Insana tradisi perkawinan merupakan sesuatu yang sakral dan wajib dilaksanakan dengan upacara yang tidak meninggalkan nilai dari adat-istiadat dan juga nilai Ketuhanan.

Sehingga "Belis" sendiri sudah merupakan suatu tradisi dalam sebuah perkawinan yang lahir, hidup dan berkembang dalam suatu masyarakat setempat yang terus-menerus dilangsungkan dan tak pernah ditiadakan dalam upacara adat perkawinan pada hidup masyarakat Nusa Tenggara Timur lebih spesifik dalam penelitian ini ialah pada tradisi "belis" masyarakat Insana yang menjadikannya terus ada hingga kini.

\section{B. Belis}

\section{Pengertian "belis"}

"Belis" merupakan kata lain dari maskawin atau mahar dalam bahasa dawanmasyarakat Nusa Tenggara Timur. "Belis" merupakan hak mutlak calon mempelai wanita dan kewajiban mempelai pria untuk memberikannya sebelum akad nikah dilangsungkan. Pelaksanaannya dapat dilakukan secara tunai dan boleh pula secara utang. "Belis" merupakan lambang tanggung jawab mempelai pria terhadap mempelai wanita, yang kemudian muncul menjadi istrinya.

Menurut Kamus Besar Bahasa Indonesia (KBBI) "belis" adalah harta yang diberikan oleh pihak laki-laki kepada mempelai perempuan pada saat melamar. Menurut pendapat umum, "belis" mempunyai arti dalam hubungan kekeluargaan adalah sebagai tanda terima kasih kepada wanita yang merelakannya pindah tempat juga sebagai hubungan keluarga baru untuk seterusnya, serta memberi nilai kepada wanita.

"Belis" juga mempunyai arti untuk menentukan sahnya perkawinan sebagai imbalan jasa atau jerih payah orangtua, sebagai tanda penggantian nama si gadis. Artinya, menurunkan nama keluarga si gadis dan menaikkan nama keluarga lakilaki. Jika tidak dilaksanakan "belis", pihak laki-laki tidak berhak atas pemberian nama suku atas nama sukunya.

\section{Fungsi "Belis"}

"Belis" mempunyai beberapa fungsi untuk pihak laki-laki dan perempuan antara lain:

a) Alat penentu sahnya perkawinan.

b) Sebagai alat mempererat hubungan keluarga.

c) Sebagai penanda bahwa si gadis telah keluar dari keluarga asal. 
d) Alat menaikkan nama keluarga laki-laki.

\section{Dampak pemberian "belis"}

Ada beberapa dampak yang didapat pada saat "belis" telah diberikan. Ada dampak positif dan negatif.Dampak positif dari pemberian "belis", antara lain:

a) Martabat keluarga laki-laki menjadi terhormat.

b) Melalui pemberian "belis" martabat keluarga laki-laki menjadi terhormat atau diangkat karena pihak pria dianggap mampu membayar "belis" yang ditentukan oleh pihak keluarga wanita.

c) Pihak keluarga wanita merasa dihargai. Maksud dari pemberian "belis" ini adalah sebagai imbalanm jasa atau penghormatan atas kecapaian, kesakitan dan jerih payah orangtua selama melahirkan dan memlihara si gadis sampai dewasa.

d) Munculnya sebuah kekerabatan baru. Dengan memberikan "belis" akan muncul sebuah kekerabatan baru antara keluarga wanita dan pria. "Belis" dijadikan sebagai pengikat.

e) Calon pengantin

Melalui pemberian "belis", calon pengantin pria dan wanita sudah mendapat restu dari orangtua dan keluarga sehingga boleh melanjutkan hubungan kejenjang perkawinan.

Adapun dampak negatif dari pemberian "belis", antara lain:

a) Martabat wanita direndahkan
Dengan pemberian "belis" kepada keluarga wanita, pihak pria merasa bisa bertindak bebas kepada wanita sehingga martabat wanita direndahkan dan wanita kurang dihargai dalam hidup berumah tangga.

b) Pihak laki-laki merasa malu

Jika pihak pria tidak mampu membayar "belis" maka pria akan tinggal di rumah keluarga wanita dan bekerja untuk keluarga wanita. Wanita merasa statusnya lebih tinggi dari pria itu sehingga pria akan merasa malu.

c) Pertentangan diantara kedua keluarga Hal ini terjadi karena "belis" yang dituntut oleh pihak wanita terlalu tinggi sehingga pihak pria tidak mampu membayarnya.

d) Menimbulkan utang piutang

Jika tak mampu membayar "belis", maka keluarga laki-laki mengambil jalan pintas dengan meminjam uang pada pihak lain sehingga menimbulkan utang piutang.

\section{4. "Belis" Yang Harus Disiapkan Mempelai Pria Sesuai Tradisi Perkawinan Masyarakat Insana}

Dalam tradisi perkawinan masyarakat Insana, sesuai dengan ciri khasnya yang mempunyai tradisi "belis" dimana harus membayar dan membawa sejumlah barang yang merupakan ungkapan terima kasih kepada orangtua mempelai wanita, maka jenis bawaan yang disiapkan oleh seorang laki-laki sebelum menikah dan dibawa pada saat malam adat, yakni: 
a) Sejumlah Uang (sesuai dengan permintaan dari keluarga wanita).

b) Emas (seperangkat perhiasan).

c) Kain Tenun.

d) 1-5 ekor ternak (sapi dan kerbau).

e) Sirih pinang.

f) Make up dan pakaian wanita.

\section{Metode Penelitian}

\section{A. Tempat dan Waktu Penelitian}

Adapun penelitian ini akan dilaksanakan di Kecamatan Insana, Kabupaten Timor Tengah Utara Propinsi Nusa Tenggara Timur. Penelitan dilakukan selama enam bulan.

\section{B. Pendekatan dan Jenis Penelitian}

\section{Pendekatan Penelitian}

Penelitian ini menggunakan pendekatan kualitatif, yaitu pendekatan yang mengungkapkan data yang diperoleh di lapangan dengan kalimat bukan angka. Endraswara (2003: 14) mengungkapkan pendekatan kualitatif mengejar data yang lebih mewakili fenomena.

Penelitian kualitatif mengutamakan data yang diperoleh di lapangan, biasa tidak terstruktur, relatif banyak dan memungkinkan untuk menata, mengkritisi dan mengklarifikasi agar lebih menarik. Pendekatan kualitatif, menjadikan mudah dalam pengambilan data, yaitu dari pelaku yang menggunakan tradisi "belis" dan juga akan diketahui bahwa benar adanya praktek perkawinan "belis" di masyarakat Insana, kabupaten Timor Tengah Utara NTT.

\section{Jenis penelitian}

Jenis penelitian ini menggunakan deskriptif analitik, yakni membangun pola pikir dengan cara bertolak dari hal-hal yang bersifat umum, dari pengatahuan, teori, hukum, dalil yang membentuk proposisi dalam silogisme.

\section{Sumber Data}

Adapun jenis sumber data yang digunakan, yakni:

1. Data Primer

Data primer adalah data yang hanya dapat diperoleh dari sumber asli atau sumber pertama. Teknik yang digunakan untuk memperoleh data adalah melalui wawancara dan pengamatan langsung saat adanya pemberian "belis" dalam tradisi perkawinan.

2. Data Sekunder

Data sekunder adalah data yang sudah tersedia sehingga tinggal mencari dan mengumpulkan. Penelitian ini menggunakan buku, dan elektronik book (e-book) untuk mendapatkan informasi mengenai "belis" dalam tradisi perkawinan.

\section{Teknik Pengumpulan Data dan Instrumen Penelitian}

\section{Teknik Pengumpulan Data}

Teknik pengumpulan data yang digunakan adalah teknik observasi, teknik wawancara, dan teknik studi dokumen.

a) Teknik Observasi

Menurut Margono (2003: 158), observasi diartikan sebagai pengamatan 
dan pencatatan secara sistematik terhadap gejala yang tampak pada objek penelitian. Pengamatan dan pencatatan yang dilakukan terhadap objek yang ungkep dulu, sehingga observasi berada bersama objek yang diselidiki, disebut observasi langsung.

Observasi adalah pengamatan langsung pada objek yang akan diteliti (Keraf, 1994: 162). Observasi bertujuan untuk membuktikan apa yang sebenarnya terjadi di lapangan sehingga paham atas informasi yang diperoleh. Pengamatan dapat diklasifikasikan melalui cara berperan serta dan tidak berperan serta (Bogdan dan Taylor dalam Sumaryanto, 2010: 99). Peneliti menggunakan observasi klasifikasi melalui cara tidak berperan serta.

b) Teknik Wawancara

Moleong (dalam Sujarweni 2014: 34) mengemukakan bahwa wawancara adalah percakapan dengan maksud tertentu yang dilakukan oleh dua pihak yaitu pewawancara yang mengajukan pertanyaan dan yang diwawancarai yang memberikan jawaban atas pertanyaan yang diajukan pewawancara.

Dalam penelitian ini menggunakan jenis wawancara yang dikemukakan oleh Sugiyono (2006: 49), yaitu pendekatan menggunakan petunjuk umum wawancara, yang mengharuskan pewawancara membuat kerangka dan garis besar pokok yang ditanyakan dalam proses wawancara.

c) Teknik Dokumentasi

Teknik studi dokumen adalah cara pengumpulan data melalui peninggalan tertulis, seperti arsip-arsip dan termasuk juga buku-buku tentang pendapat, teori, dalil, atau hukum-hukum, dan lain-lain yang berhubungan dengan masalah penelitian (Margono, 2003: 181).

Studi Dokumentasi adalah suatu teknik pengumpulan data dengan cara menghimpun dan menganalisis dokumen-dokumen, baik dokumen tertulis, gambar, hasil karya, maupun dokumen-dokumen bentuk elektronika.

\section{Instrumen Penelitian}

Dalam penelitian ini, adapun instrumen yang dipakai, yakni:

a) Peneliti sendiri yakni peneliti yang menjalankan penelitian atau melakukan observasi dengan apa yang ingin diteliti.

b) Alat bantu dalam penelitian yakni kamera, buku, alat tulis, tape recorder dan telepon genggam.

\section{Hasil Dan Pembahasan}

\section{Hasil Penelitian}

\section{A. Sejarah "belis" dalam tradisi perkawinan masyarakat Insana}

Masyarakat Insana adalah masyarakat yang hidup dan memegang adat-istiadat dan dikatakan sebagai masyarakat hukum adat. Dalam segala 
aspek kehidupan selalu disertai dan dikaitkan dengan adat-istiadat salah satunya ialah dalam hal perkawinan.

Adapun pemberian mahar atau mas kawin yang lebih dikenal dengan istilah "belis" untuk masyarakat Timor pada umumnya dan Insana pada khususnya. Adapun yang menjadi suatu yang patut diketahui mengenai dengan sejarah pemberian "belis" dalam tradisi perkawinan masyarakat Insana, seperti yang diungkapkan oleh FH-1 tentang sejarah adanya pemberian "belis":

Belis unu' hit Usi sin mnui jiana feto, loh kalo jiana feto karna npoe natuin in naefa in moenla toh jadi onle lo le usif sin anhin matsao nok an mone nokoh usif bian sin anhin. Kalu sin matsao loh le sin nemat fe le bale, bale ih onle mnatu, loe perak, bikase, bijae, bijaemeto, naijan, bete-tais. Loh le karna le hit amnaestin nail le humaf on ih le sinan msat natuin. Karna nak bifela in aina-ama nasuspen npao sin anfeto jadi kalau atone hen matsao nokan harus an fe le puah mah mamtes hen sekal leh bifela aina-ama sin haeta. Waktu nane loh leh masi kah jiana usif masi le atoen meto biasa msat npaek le humaf nan hen natuin man nbaen sin belis (Wawancara, 01 Juni 2017)

(Artinya adalah "Belis" itu dulu waktu kita punya Raja mereka mempunyai anak perempuan, dan karena anak perempuan itu akan nikah dan akan ikut dengan suaminya, hidup dan meninggalkan keluarga dan dulu anak rajapun harus menikah dengan sesama keluarga bangsawan entah dari kerajaan dalam lingkup dekat atau jauh. Keluarga lelaki akan memberikan imbalan berupa emas, uang perak, sapi, kerbau, tanah, kain tenun. Dan karena orangtua dulu atau nenek moyang kita melihat hal tersebut maka merekapun mengadopsi tradisi tersebut. Karena orangtua dari perempuan sudah menjaga dan memelihara hingga anak perempuannya tumbuh dan cantik maka adapun dikasih sirih-piring yang dalam artian berkembang hingga kini dan dinamakan "belis". Darisitulah istilah sirih-pinang (belis) dipakai dalam lingkup keluarga raja ataupun orang awam biasa juga mengadopsi kebiasaan itu hingga kini).

Hal senada juga diungkapkan oleh FH-2 ketika ditanya mengenai sejarah adanya pemberian "belis" dalam tradisi perkawinan masyarakat Insana.

Le hit mnaesin nail natuin le usif sin usif le abit pah le ih mah nok le usif noko Biboki mah Beulsinkarna nak le feh puah mah manus nan sin ntulun leh bifela in ama-aina mah sin biakin oke' noko le nan hit be'e mah na'i sin msat natuin onle le uisfin. Natuin hen nbaen beles. Mah sin baekan paek fah mnatu nok loe perak (Wawancara:03 Juni 2017)

(Artinya adalah Nenek moyang kita melihat dan mengikuti kebiasaan para raja yang ada dilingkup kerajaan Insana atau pada kerajaan Biboki dan Belu karena dengan memberikan "belis" berupa penghargaan yang besar buat keluarga perempuan dan merupakan ungkapan terima kasih yang besar. Pada saat itu nenek moyang kita juga mulai mengikuti untuk membayar "belis". Tapi pada saat itu nenek moyang kita yang bukan dari keluarga bangsawan hanya mematok seadanya tanpa memakai bayaran "belis" berupa emas dan uang perak).

Pendapat yang sama juga didapat dari FH-03 yang bercerita tentang sejarah adanya pemberian "belis" dalam masyarakat Insana:

Unu' hit be'e mah na'i sin alaha nlael meo mah nok apaot ume sepe sin onat mui hit usif es nmui anfeto, anfeto ih 
namas in namas es leh bifeh bian. In tenot nahian, nahanat makoe, hen bili msat nim'na alekot. Atone-atone bin pah bian nahian leh in masna ijah oke. Onat mui atone es in ama msat usif noko beolsa naeh nem he ntoet le bife ih. In nemat nek tua nakaf mah puah nok manus. Loh le hit usif ijah nloem hen matsao in an feto ih msat. Usif ih nem nok in aina-ama sin oke nem te nek mnatu, bete-tais, loe perak, bijae, bijae meto. Nak hen tulun le bife ijah in ainaama karna nloem ben he in matsao mah nek sin an feto amasat ih. Noko le nan hit mnaes fin nail on nan jadi sin msat natuin nteh sin anfeto msat kalu mnui atone hen toet sin ana lof sin fe puah mah manus onle uisfin onle nane le ntea muni ih hit tatuin onle nan (Wawancara: 05 Juni 2017).

(Artinya adalah dahulu nenek moyang kita hanyalah menjadi prajurit atau hanya menjadi penjaga rumah adat dan rumah kerajaan. Raja kita mempunyai putri yang sangat cantik, ia pintar menenun, rajin dan pandai menari. Kalau ia menari tangannya gemulai, dia snagat cantik dan cantiknya melebihi perempuan lain di kampung dan kerajaan itu. Sampai suatu ketika ada seorang pria dari kerajaan belu dan datang untuk melamar putri itu. Pria itu datang membawa sopi kepala murni (alkohol kampung) dan sirih pinang. Pinangan itu diterima dan datanglah pria itu bersama keluarganya membawa serta emas, uang perak, sapi, kerbau, dan hasil kain tenunan.

Alasan mereka membawa bingkisan tersbeut ialah berupa ungkapan terima kasih karen atelah merestui lamaran tersebut dan telah mengiklaskan anak mereka untuk hidup bersama pria. Dari situ nenek moyang melihat hal itu dan hingga kini jika mereka mempunyai anak perempuan setiap kali lamaran pasti dibicarakan "belis" atau seserahan yang akan diberikan laki-laki atau pihak keluarga pria kepada perempuan. Hal itu berlanjut hingga kini).

\section{B. Nilai-nilai dalam tradisi "Belis"}

Setiap benda, bangunan bahkan suatu tradisi dalam lingkup kehidupan pasti memiliki nilai-nilai yang sangat tinggi dan bisa kita pelajari sebagai suatu bentuk penghargaan terhadap yang terdahulu telah melestarikan suatu kebudayaan. Oleh sebab itu, nilai-nilai itu sangatlah bermanfaat bagi masyarakat khususnya para generasi penerus. Begitu pula dalam tradisi "belis" dalam perkawinan pada masyarakat Insana juga memiliki nilai yang bisa kita mengerti dan pelajari. Dalam wawancara tentang nilai yang terkandung dalam "belis", beberapa penjelasan, diantaranya:

Diungkapkan oleh FH-1 mengenai nilai dalam tradisi "belis" ialah sebagai berikut:

Beles kalu hit he tauab le in nilai sin lo le nilai budaya,nilai sejarah mah nok nilai sosial. Aufeha contohe, kalu sejarah nane karna le beles nane noko unu' tea le muni ih mnui in sejarah noko hit mnaesfin le hit bisa tpaek le humaf nan kan bisafah he hit sekal nok sa'sah.kalu le budaya nane neofun hit terus tpaek beles bin me'me atone hen matsao harus mnui beles masih usif kah atoen meto kah sakah-sakah. Kalu uab le mak sosial nane neofun hit het talekob hit monek mah nok hit biakin (Wawancara: 01 Juni 2017).

Berbicara tentang "belis" dan tentang nilai-nilai yang terkandung dalam "belis" ada nilai sejarahnya atau historis, nilai budaya, dan nilai sosial. Biarkan saya memberikan contohnya kalau nilai historisnya tentu "belis" ini merupakan suatu peninggalan kebudayaan dari nenek 
moyang kita dan sampai kini kita masih mengadopsinya dan tidak bisa kita ganti dengan apapun.

Dalam nilai budaya sama halnya dengan nilai historis karena hingga kini tradisi itu masih kita pakai dan perbaharui. Dimana-mana semua masyarakat kita memakai "belis" meski itu kaum raja, bangsawan dan orang awam. Kalau dalam hal nilai sosial "belis" itu mempersatu/mempererat tali hubungan keluarga besar kedua mempelai dan juga menjaga nama baik keluarga besar.

Hal yang hampir sama dikatakan oleh FH-2 yang menjelaskan tentang nilai dalam belis.

Beles nmui in mnui nilai nmes, nmui nilai sejarah mah nilai budaya. Sejarah neofun tamolok le nan nane nmui nokoh hit ahun'tin'na aih hit be'e nai sin, onat beles nane hit kat karang fah aih hit kah moe'sok nmes. Budaya nane bin me leh het feh beles nane nokoh unu' hit paek ben. Karna hit pao le hit na'i-be'e sin feh kit. (Wawancara: 03 Juni 2017).

Belis mempunyai nilai historis dan budaya. Historis dimana bawasannya pemberian belis dalam tradisi masyarakat Insana, suatu tradisi yang dilestarikan sejak nenek moyang. Belis itu tidak dikarang atau dibuat-buat. Nilai budaya dimana hal pemberian "belis" dalam tradisi perkawinan masyarakat Insana merupakan tradisi yang bukan hanya karena sering dilakukan terus menerus namun lebih kepada menjaga dan menggabungkan adat-istiadat didalamnya guna menjaga suatu perkawinan. Sementara pendapat lain oleh FH-3 bahwa:

Nmui ha nilai nokoh le beles nane nmui in sejarah, in budaya, in sosial mah nok in ekomoni. Tail nokoh in sejarah beles nfe kit nilai le noko unu' onat fe hit paekleh teah muni' ih. Noko in nilai budaya hit terus tpaek le beles ih tea neno ih. Onat kalu teak in nilai sosial nane artinya nokoh beles hit pao hit moneh nok hit keluarga sin ok'oke nokoh bife in'ni aih atone in'ni. Tek tan in nilai ekonomi nane atone nbaen na'fani leh hit aina ama sin haeta (Wawancara: 05 Juni 2017)

Ada empat nilai yang terkandung dalam "belis" yakni nilai sejarahnya, budayanya, sosialnya dan ekonominya. Dilihat dari nilai sejarahnya "belis" memberikan suatu nilai yang telah diadakan sejak dulu kala dan masih tetap eksis hingga kini. Dalam nilai budaya dengan terus-menerus melihat perkembangan "belis" dalam kehidupan masyarakat sekitar yang tidak pernah meninggalkan suatu tradisi artinya kita menjaga budaya yang telah diwariskan.

Nilai sosial yakni menjaga keutuhan keluarga besar kedua belah pihak calon mempelai dan menjaga kekerabatan. Sedangkan nilai ekonomi dari "belis" ialah dengan kembalinya pergantian rugi atas kelelahan dari orangtua perempuan yang telah menjaga dan merawat serta membesarkan belum lagi menyekolahkan perempuan hingga tumbuh besar dan menjadi seorang perempuan yang cantik dan harus meninggalkan mereka untuk tinggal dan hidup bersama pria. 


\section{Pemberlakukan "belis" dalam tradisi perkawinan di Insana}

Suatu daerah tentu mempunyai kebudayaan atau tradisi yang sudah dipakai atau diberlakukan sejak dahulu kala. Dan tentu kebudayaan atau tradisi itu mempunyai suatu makna yang penting. Bagi kebanyakan orang yang belum paham akan kebudayaan atau tradisi itu akan menjadi suatu pertanyaan besar dalam benak mereka mengapa tradisi itu harus ada dalam kehidupan masyarakat ini. Itupun yang menjadi suatu pertanyaan mengapa "belis" diberlakukan dalam tradisi perkawinan masyarakat Insana.

Dalam penelitian ini seperti yang diungkapkan oleh $\mathrm{FH}-1$ tentang pemberlakuaan "belis" dalam tradisi perkawinan masyarakat Insana yang mengatakan bahwa:

Hit tabal ih tpaek beles kah untuk selama het sos bife atau ta'sosa' hit anfeto tapi tpaek beles bin matsao'sa naeofun hit be'e mah na'i sin paekben nokoh unu. Onat le beles le nan msat neo het tahian kalu anmone le nane serius nok hit anfeto artinya bisa tanggung jawab (Wawancara: 01 Juni 2017).

Dalam kehidupan berbudaya kita, tidak selamanya memakai tradisi "belis" artinya menjual atau membeli perempuan tapi kita memakai tradisi "belis" karena ini adalah suatu budaya yang sudah dipakai sejak lama oleh nenek moyang kita. Dan juga pemakaian "belis" dalam perkawinan itu juga sebagai salah satu bukti bahwa jika pria serius dan bertanggung jawab dengan anak perempuan yang ingin dinikahi itu.

Ungkapan yang senada juga disampaikan oleh FH-2 mengatakan bahwa:

Atoen Insana, kalau tauab le tentang nansa npaek beles bin urusan matsao'sa loh ala'ha tak nane moe'le ben nokoh unu' neofun beles le nane tradisi aih adat-istiadat le kaisa hit kat pio taenle fah. Neofun beles bit le hit hianlah nmui hubungan nok mas okan sin (Wawancara: 03 Juni 2017).

Masyarakat Insana dalam tradisi perkawinan memberlakukan "belis" karena "belis" adalah tradisi atau adat-istiadat yang tidak boleh diabaikan. Sebabnya "belis" dalam kepercayaan tradisi memiliki hubungan dengan leluhur. Adapun hal yang sedikit berbeda disampaikan oleh FH-3 yang mengungkapkan bahwa:

Bin Insana kalu ta'uab soal matsao'sa berarti ta'uab soal beles msat nane pasti. Kalu tek tanok tentang le nansa mah hit bin ih harus paek "belis" ai nansa matsao sa harus tek beles nane le pertama neofun noko unu' loh on nan harus tatuin hit budaya talah leh muni ih. Onat neofun beles nane istilah terima kasih neo le bife in aina-ama karna in aina ama mui ji'ana feto in nahoen, na'naebe, naskolbeh, napaek beh talah in anfeto na'nae onat namas on le ih le hom loeme he him matsao. Onat matsao milael mek au anha neo hi umeh ben, mitam au ana neo hi uem leu ben jadi lo le istilah terima kasih ih ho baen neo kauh karna natuin le auih le ho bisa mupen bife on au anfeto ih (Wawancara: 05 Juni 2017).

Di Insana, kalau berbicara tentang perkawinan berarti berbicara tentang "belis", dan itu pasti.kalau berbicara tentang mengapa dalam kehidupan mayarakat 
Insana harus memakai "belis" dalam tradisi perkawinan yang pertama itu karena merupakan budaya yang sudah terjadi turun-temurun yang sudah diwariskan dan harus terus diikuti budaya hingga sekarang. Kedua, "belis" itu merupakan ungkapan terima kasih untuk orangtua pihak perempuan karena dia sudah melahirkan, menjaga, merawat, menafkahi, dan menyekolahkan anak perempuannya hingga tumbuh besar seperti sekarang ini hingga ada yang jatuh cinta dan mau menikah dengannya.

Jika sudah menikah, tentu anak perempuan anak dibawa ke rumah laki-laki dan tinggal disana sedangkan orangtua anak perempuan tidak punya apa-apa. Inilah bentuk ungkapan terima kasih dna penghargaan terhadap keluarga pihak perempuan dan ungkapan menghargai derajat perempuan.

\section{Pergeseran makna "Belis" Tahun 2000-2017}

Suatu kebudayaan yang sudah ada sejak dahulu dan merupakan warisan dari nenek moyang yang mendiami suatu masyarakat, terlebih lagi kebudayaan atau tradisi itu masih terus bisa berkembang di tengah masyarakat yang terus-menerus mengikuti perkembangan zaman tentu mempunyai pergeseran nilai atau perubahan. Salah satunya yakni "belis" yang merupakan tradisi yang sudah ada sejak lama dalam masyarakat Insana yang masih terus-menerus berkembang hingga diusia yang tua ini. Adapun hasil yang didapat dari penelitian ini mengenai tradisi belisdari tahun 2000 sampai 2017, seperti yang diungkapkan oleh FH-1:

Beles tea lekah msat in tetap beles hanya kalu ta'uab hanya in berubah bin le jumlah. Unu', beles le nane atone nbaen npaek naijan, loe perak, mnatu, bjaemeto, bijae mok bete mah tais. Muni' ih atone sistem nbaen mnui nabal dulang hiut. Nmui istilah napaek na'fani jianfeto, onat kalu in ana naskola naek beles msat nasaeb, kalu in nokoh keluarga naek lof in anha msat banit ih mahal. Bife in aina ama in nasaeb leh beles nan eneofun bianin natuin le atone bian sin kebiasaan te (Wawancara: 01 Juni 2017).

"Belis" itu sampai kapanpun akan tetap "belis" hanya jika berbicara tentang situasi sekarang tentu ada sedikit perubahan dan pergeseran dalam artian jumlah. Dulu, sistem pembayaran "belis" orang-orang memakai bidang tanah, uang perak, emas, sapi, kerbau dan hasil tenunan berupa kain tenun. Sekarang sistem pembayaran "belis" itu memakai istilah membawa tujuh dulang yang mempunyai isi berupa-rupa.

Ada juga yang jika anak perempuannya berpendidikan tinggi tentu "belis" yang akan dibayar berbeda atau lebih mahal serta jika anak permepuan itu dari keluarga besar atau terpadang, meski bukan berdarah bangsawan "belis" pun ikut mahal. Adapula dari beberapa keluarga atau marga lain ikut kebiasaan orang lain atau suku lain dan tidak mau kalah dalam mematok harga bayar "belis". Pendapat 
yang sama juga diungkapkan oleh FH-2 yang mengakatan bahwa:

Hit tabal ih kah bisa fah he tak belsa lo tetapha, lof tiap fam sin jah lof onle naik'nin. Keluarga es nok sin mes'mese teh naikan. Loh le beles ih tabal ih unu te alaha btaen loe perak mah mu'it. Muni ih, alaha hem baen loet. Nes-nes kalu in anfeto naskolah naek lof sin tekas ijah naek. (Wawancara: 03 Juni 2017).

Kita di sini tidak bisa dikatan kalau "belis" itu akan tetap saja dan tidak ada perubahannya, perubahannya itu pasti tergantung cara pandang keluarga pihak permpuan karena sekarang di era ini apalagi beberapa tahun terakhir mereka lebih lihat kepada status pendidikan anak perempuan. Jika tingkat pendidikannya tinggi maka bayaran "belis" yang harus dibawa pun sedikit berbdeda atau cenderung lebih mahal atau tinggi.

Terdapat perbedaan dengan kedua pendapat di atas, seperti yang diungkapkan oleh FH-3 tentang nilai "belis" setiap dekadenya bahwa:

Beles in up'fa berubah aih naikan nane neofun mnui hubungan nok nilai ekonomi mah nok le loeta msat. (Wawancara: 05 Juni 2017).

Belis nilainya berubah atau sedikit mendpaat pergeseran karena mempunyai hubungan dengan nilai ekonomi dimana berubahnya nilai rupiah).

\section{E. Jenis "belis" yang menjadi seserahan atau simbol sahnya perkawinan}

Tiap daerah atau suku masyarakat tertentu mempunyai ciri khas tersendiri dalam memandang dan menjalankan tradisi perkawinan terlebih lagi perkawinan adat. Dalam masyarakat Insana yang mempunyai istilah bayar "belis" atau mahar, tentu mempunyai bentuk atau jenis seserahan yang berbeda dengan "belis" atau mahar di daerah lain. Berikut adalah ungkapan dari FH-1 yang mengatakan bahwa:

Kalu hen matsao, lof le atone nane nsiap naen nak he nek sa'sa'. Bin Insana biasa loh loet perak, kalu loet perak kanmuifa lofan sekal nok loet kertas biasa. Lofan mnui nok mu'it nane lof bijae lah mese kah nuh' ai bijae meto tapi jarang kan paek kah bijaemeto ben. Onat mui nok oema putu-ai malala nane in up'fa lebih naek. Biasa rata-rata tabal hit ih nbaen le oema putu ai malala nane biasa juta boa'nuh tea juta nim. Nane biasa nbaen pas malam adat. Baba' sin biasa mui peranan khusus dalam te matsaosa. Lof sinan esan teak le beles bianin selain leoe maputu ai malala(Wawancara: 01 Juni 2017).

Kalau mau menikah, tentu dari pihak laki-laki sudha terlebih dahulu mempersiapkan segala sesuatu yang berkiatan dengan apa-apa saja yang harus ia bawa. Di Insana, biasanya sistem pembayaran "belis" yang sering dijumpai ialah uang perak itu nilainya mahal sekali dan sulit dijumpai maka akan diuangkan saja dengan uang kertas. Lalu adapula hewan atau ternak yang dibawa berupa sapi dan kerbau namun kerbau sudah jarang sekali jadi hanya sapi yang berkisar satu sampai tiga ekor.

Adapun istilah air susu ibu, itu biasanya berbeda lagi. Patokannya biasa sekitar dua puluhan juta sampai lima puluh juta dan harus dibawa saat malam adat. Di 
Insana, jika upacara menikah, Om kandung dari perempuan atau saudara kandung dari Ibu akan punya peranan penting dlaam meminta seserahan namun tidak dalam hal air susu ibu. Adapun pendapat yang hampir sama diungkapkan oleh FH-2 bahwa:

Bin Insana ih kalu he adat tetang amatsao'sa, lofan mui tiga urutan biasa le pertama inja tio-oko atau puah matotis maon matotis. Ijah biasa nakam tahap awal hen toten bife noko atone in keluarga. Kedua, oe maputu ai malala ijah onle simbol penghargaan le in baentah loh suk. Ketiga, puah mnais manu mnasi atau puah oe nun-manus oe nun. Nokoh le teon'in ih hen tek oe maputu-ai malala biasa le hen toet nane lof bifelah in aina-ama hone nan ehe nek loet mah mah mu'it onat puah mnasi manu mnasi nane lof het tek le nan lof noko atoen amaf ai sin baba', aina in na'o hone(Wawancara: 03 Juni 2017).

Dalam masyarakat Insana jika berbicara tentang perkawinan adat ada tiga macam jenis tahapan dalam perkawinan Insana dan itu berbeda setiap bawaannya. Yang pertama yakni permintaan awal dari pihak laki-laki yang meminta izin kepada keluarga permepuan dengan membawa sirih pinang, beberapa uang, dan sopi yang merupakan bawaan secara spontan dari pihak laki-laki.

Kedua adalah air susu ibu yang merupakan sebuah simbol dari penghargaan terhadap orang tua perempuan dan yang jumlahnya juga terbilang luamayan. Sedangkan yang ketiga ialah jenis bawaan untuk para paman dari ibu kandung. Dari ketiga jenis diatas, yang menjadi hak utuh orangtua ialah air susu ibu dan untuk yang ketiga ialah bentuk hormat kepada paman dari saudara laki-laki ibu. Pendapat lain juga diungkapkan oleh FH-3 yang mengatakan bahwa:

Bin hit ih kalu atone hen matsao lofan nek leh beles nane huma'-huna'. Tahap awal lofan nek tio-oko atau puah matotis maon matotis. Ijah biasa nakam tahap awal hen toten bife noko atone in keluarga. Nane lofan nek le tuah, loeta an'nes nok mamat. Kalau bin in adat ben mui nakam oe maputu ai malala nane le hit tak an beles nane lofan nek loet jumlah noko bife in aina sinan toten, onat lofan nek'ken ten dulang hiut nane nokoh mnatu, sabalu, istilah napaek na'fani le bife lah. Onat $n k$ bijae (Wawancara: 05 Juni 2017).

Di wilayah masyarakat Insana jika dalam hal perkawinan dan pembahasan tentang "belis" bawaan akan bermacammacam.Tahap awal dalam hal melamar akan dibawakan sapi atau minuman alkohol kampung, beberapa jumlah uang yang tidak smapai pada nilai juta, dan sirih pinang.

Lalu dalam tahap adatnya itu biasa akan dibawakan tujuh dulang didalamnya sudah termasuk air susu ibu. Itu berupa uang, uang perak, emas, pakaian untuk wanita dari ujung kaki sampai rambut. Dan juga membawa ternak berupa sapi.

\section{F. Tanggapan masyarakat Insana} terhadap budaya "belis"

Masyarakat Insana menjadikan "belis" sebagai salah satu syarat dalam tradisi perkawinan mereka.. "Belis" yang sudah ada sejak lama dan terus-menerus dilestarikan dalam kehidupan masyarakat. "Belis" yang merupakan suatu simbol 
sahnya perkawinan adat di masyarakat Insana wajib dibayar oleh mempelai pria yang nantinya menjadi Istri. Jumlah "belis" ditentukan oleh kesepatakan dari keluarga kedua calon mempelai. Dalam suatu kebudayaan atau tradisi di daerah, tentu mempunyai pandangan dari kaum penganut kebudayaan.

Seperti halnya "belis". Adapun tanggapan dari masyarakat Insana tentang "belis", yang diungkapkan oleh FH-1 yang mengatakan bahwa:

Nokoh hai sebagai amnasit hai kam keberatan ai haim siom le beles nane neofun karna nane nokoh unu' ee. Karna kalu siap hem matsao harus amsiap le' beles nan (Wawancara: 01 Juni 2017).

Dari saya selaku orang tua dan adat kami sama sekali tidaklah keberatan dengan "belis". Kami sangat menerima tradisi "belis" karena itu adalah tradisi. Sebab jika siap ingin menikah berarti siap untuk membayar "belis". Hal lain diungkapn oleh FH-2, bahwa:

Beles nane hit paek'le nokoh unu'ben. Bin hit ijah, kan mui fah tanggapan neo le beles nane karna sin nahian kalu beles nane harus tbaen kalu het matsao onat kalu mui (Wawancara: 03 Juni 2017).

Tanggapan masyarakat Insana terhadap budaya "belis" yang telah dilakukan turun-temurun adalah pada umumnya masih belum ada tanggapan. Barangkali yang ditanggapi ialah jumlah "belis" yang ditentukan oleh pihak keluarga perempuan. Tanggapan boleh, namun pihak laki-laki tidak mempunyai hak untuk menurunkan kecuali negosisasi secara internal maka pertimbangan nurani kemanusiaan tetap ada. Adapun yang diungkapkan oleh FH-3 bahwa:

Tabal ih tabal hit ih kan muifah hen keberatan neo le beles hanya kalu onle kan'nabe'fa bisa sin bisa ntawar. Atone insana sin biasa nseom le beles nane. Karna mak hem matso jadi nmui beles harus siap ee (Wawancara: 05 Juni 2017).

Di Insana, tidak ada yang keberatan dengan adanya "belis" dalam tradisi perkawinan hanya kadang kala, adanya jumlah yang lebih dan tidak sanggup dibawa oleh pihak laki-laki maka akan adanya sistem tawar-menawar dari pihak keluarga laki-laki. Karena setiap orang di Insana sudah tahu bahwa jika ingin menikah berarti harus menyiapkan "belis".

\section{Pembahasan}

\section{A. Sejarah "belis" dalam tradisi perkawinan masyarakat Indonesia}

Suatu kebudayaan yang ada dan telah diadopsi oleh suatu masyarakat dalam suatu lingkup hidup tertentu punya suatu sejarah mengapa kebudayaan tersebut bisa ada, dan menyebar di daerah tersebut. Demikian juga "belis" yang menjadi suau tradisi dalam perkawinan masyarakat Insana tentu mempunyai sejarah.

"Belis" merupakan suatu bentuk penghargaan kepada wanita dan juga tanda terima kasih kepada keluarga dan orang tua wanita dalam bentuk seserahan atau barang bawaan yang diberikan kepada pihak keluarga wanita saat upacara perkawinan 
adat. "Belis" juga diadopsi oleh masyarakat Insana dalam tradisi perkawinan.

Melalui wawancara kepada orang tua dan tua adat di Insana, diketahui bahwa sejarah "belis" dalam tradisi perkawinan Insana merupakan suatu kebudayaan atau tradisi yang dianut oleh para leluhur atau nenek moyang masyarakat Insana yang telah mengadopsi kebiasaan dari para Raja.

Menurut cerita bahwa konon, leluhur mayarakat Insana melihat tradisi perkawinan dari para Raja Insana yang mendapat bingkisan atau seserahan dari calon mempelai pria dari putri mereka berupa emas, uang perak, tanah, tenunan, sapi, dan kerbau sehingga para leluhur msayarakat Insana mengadopsinya dalam tradisi perkawinan mereka.

Leluhur masyarakat Insana melihat suatu perkawinan sebagai suatu yang sakral dan sangat dijaga. Leluhur mayarakat Insana melihat bahwa "belis" merupakan suatu bentuk penghargaan kepada seorang wanita dan juga sebagai suatu bentuk tanda terima kasih kepada orangtua wanita oleh sebab itu "belis" dipakai dan dijadikan budaya masyarakat Insana hingga kini.

\section{B. Nilai Yang Terkandung Dalam "Belis"}

Seperti halnya "belis", mempunyai nilai yang terkandung di dalamnya, yaitu:

1. Nilai Historis

"Belis" bukan hanya dipandang sebagai suatu bawaan atau seserahan yang sifatnya memberatkan pihak lakilaki dalam tradisi perkawinan di masyarakat Insana namun "belis" diyakini oleh masyarakat Insana sebagai suatu tradisi yang telah ditinggalkan oleh para leluhur. Dikatakan memiliki nilai historis karena "belis" sudah ada dan melekat dalam diri masyarakat Insana. "Belis" lahir dan tumbuh dari jiwa masyarakat Insana melalui para leluhur.

Dengan adanya "belis" maka derajat seorang wanita diangkat dan dihargai. Bukan hanya kepada wanita saja, namun kepada orangtua wanita melalui "belis" air susu Ibu. Masyarakat Insana percaya bahwa "belis" dan perkawinan adat dalam masyarakat Insana adalah sesuatu yang tidak bisa dipisahkan.

2. Nilai Budaya

Perkawinan adalah hal yang sakral. Perkawinan adat merupakan suatu yang perkawinan yang dilangsungkan secara adat dan juga dalam kehidupan masyarakat Insana, perkawinan adat dilaksanakan dengan permohonan izin dari para leluhur. Tradisi perkawinan masyarakat Insana tidak terlepas dari "belis". "Belis" dalam masyarakat Insana dipandang sebagai sesuatu nilai budaya karena ikut melestarikan budaya yang telah ditinggalkan oleh leluhur.

Masyarakat Insana menaruh "belis" dalam suatu tingkatan penting sebab dengan "belis", mereka telah menjalankan upacara yang ditinggalkan oleh leluhur terus-menerus. Sehingga jika berbicara soal perkawinan maka 
berbicara juga tentang "belis" yang merupakan suatu nilai budaya yang erat hubungannya dengan masyarakat Insana. Sesuai dengan uraian tentang nilai yang terkandung dalam"belis" pada tradisi perkawinan masyarakat Insana, "belis" mempunyai nilai khusus yang bukan hanya dinilai sebagai suatu tradisi yang tanpa nilai dan hanya menjadi beban bagi kaum laki-laki yang ingin menikah.

"Belis" mempunyai kapasitas sendiri yang dianggap bukan hanya soal barang bawaan ataupun suatu desakan namun lebi daripada itu, "belis" mempunyai nilai budaya yang melestarikan suatu upacara yang sejak dahulu telah dilakukan untuk terus berkembang di dalam kehidupan masyarakat.

\section{Latar Belakang Pergeseran makna} "belis" Tahun 2000-2017

\section{Makna filosofi "belis" yang} sesungguhnya adalah sarana pengikat tali silahturami antara keluarga atau marga yang saling menihkan anaknya dan berharap dapat membangun kehidupan saling menolong. Kearifan budaya yang terkandung dalam konsep "belis" adalah kekuatan atau daya adat-istiadat dalam kepercayaan masyarakat Insana.

Dahulu "belis" dapat berupa bendabenda yang sulit didapat seperti uang perak dan juga jumlahnya selalu sesuai dengan kebiasaan yang ada dalam marga tertentu. Pada kurun waktu sekitar penghujung tahun 1990-an dan masuk pada tahun 2000, "belis" mulai mengalami pergeseran. "Belis" sudah meninggalkan nilai yang sesungguhnya dan beralih pada tingkat menghitung untung dan rugi atau lebih kepada melihat seberapa besar pengeluaran orangtua terhadap anak perempuannya dari kecil hingga dewasa.

Berbeda lagi dengan yang terlahir dari keluarga bangsawan maka "belis" nya akan semakin mahal. Jika dilihat dari kaum awam, maka anak perempuan yang memiliki pendidikan yang tinggi maka "belis"nya pun akan berbeda dengan yang hanya sebatas SMA atau SMP. Dan juga adanya pergeseran nilai rupiah dan sulitnya mendapatkan uang perak maka diganti dengan bawaan yang lain.

Dalam pengertian yang diketahui "belis" yang merupakan bentuk penghargaan kepada perempuan dan juga bentuk terima kasih kepada orangtua perempuan di mana di Nusa Tenggara Timur pada umumnya yang mengikuti garis keturunan Ayah (patrilineal) adalah hasil tradisi yang ditinggalkan oleh leluhur namun semakin ke zaman yang modern "belis" mendapat pergeseran makna.

Jika sebenarnya "belis" dibayar dengan uang perak, emas, sapi, kerbau, tanah, dan kain tenun maka sekarang pengganti atas uang perak yang sudah langkah akan diuangkan dengan jumlah yang tidak sedikit diantaranya diatas $\mathrm{Rp}$. 25.000.000 (dua puluh lima juta rupiah). Antara air susu ibu dengan bawaan wajib 
lain yang harus dipersiapkan oleh pihak laki-laki sudah keluar dari makna "belis" yang sebenarnya, istilahnya pada tujuh belas tahun terakhir pada masyarakat Insana, "belis" sudah tidak melihat lagi dari pengertian "belis" yang sebenarnya dan lebih memperhitungkan nilai ekonomi.

Sesuai dengan data yang didapat, pada tahun 2000 sampai tahun 2005, tradisi "belis" tidak jauh berbeda dengan tahuntahun sebelumnya hanya saja dengan sulit mendapatkan uang perak, maka sudah mulai diuangkan dan tetap dengan bawaan lainnya. Pada tahun 2005 sampai tahun 2010 pergeseran makna "belis" mulai jelas terlihat dengan pematokan harga dari sejumlah suku dan keluarga tanpa melihat latar belakang mereka namun hanya mengikuti tradisi dari suku lain di luar Insana dengan membayar "belis" lebih mahal lagi dan disesuaikan dengan tingkat pendidikan dengan ditambahnya jumlah uang dan jumlah sapi atau ternak yang harus dibawa.

Sedangkan pada kurun waktu antara tahun 2010 sampai tahun 2017, jelas terlihat berbeda dengan tahun-tahun sebelumnya sebab dilihat dari nilai ekonomi dan nilai mata uang rupiah. Contohnya, jika pada tujuh tahun lalu seorang wanita yang berlatar belakang pendidikan D3, "belis" yang dibawa oleh calon suaminya sekitar Rp. 20.000.000, maka pada tahun ini sudah tidak lagi dengan nilai tersebut namun dinaikan sedikit sesuai dengan nilai mata uang. Dalam wawancara yang dilakukan terhadap tua adat, pergeseran nilai dari "belis" merupakan hasil dari perundingan orangtua dan hampir semua di Insana sudah mengikuti tradisi dari suku lain diluar Insana.

Namun masyarakat Insana tidak mematok "belis" lebih mahal dari suku luar Insana yang "belis"nya di atas Rp. 60.000.000 (enam puluh juta rupiah).Yang lebih mendasar dari pergeseran makna "belis" hanyalah antara pendidikan dari anak perempuan yang ingin dinikahi dan juga status atau latar belakang keluarga bangsawan atau awam.

\section{Penutup}

\section{A. Simpulan}

Berdasarkan hasil penelitian tersebut, dapat disimpulkan sebagai berikut. 1. "Belis" memiliki nilai yang erat hubungannya yakni nilai historis dan nilai budaya. Dimana nilai histroris dari "belis" ialah suatu peninggalan tradisi dari leluhur dari masyarakat Insana dan diyakini memiliki hubungan erat dengan leluhur melalui adatnya. Sedangkan nilai budaya dari "belis" yakni "belis" masih terus dilaksanakan oleh semua golongan dalam masyarakat Insana dan merupakan tradisi yang erat hubungannya dengan kehidupan masyarakat Insana dalam proses sakral sebuah perkawinan.

2. Makna "belis"yang mendapat pergeseran dalam kurun waktu 2000 sampai 2017 
atau 17 tahun terakhir dikarenakan adanya pergeseran nilai mata uang, sulitnya mendapatkan uang perak dan kerbau sehingga diuangkan dalam bentuk uang kertas. Pergeseran makna "belis" dikaitkan dengan latar belakang anak perempuan dari keluarga bangsawan atau tidak, dan juga dikaitkan dengan tinggi rendah pendidikan dari anak perempuan yang akan menikah ditentukan dari pihak perempuan.

\section{B. Saran}

1. Bagi masyarakat Insana

Bagi masyarakat Insana agar terus melestarikan "belis" dalam tradisi perkawinan adat, namun tetap melihat dari makna "belis" yang sebenarnya dan nilai yang terkandung dalam "belis" dengan tidak terlalu memberatkan kepada pihak keluarga pria.

2. Bagi Universitas PGRI Madiun

Sebagai tambahan dokumentasi dan koleksi hasil penelitian sebagai referensi untuk menambah wawasan serta kajian.

\section{Daftar Pustaka}

Alexander, U. 2015. Filsafat Kebudayaan: Kontruksi Pemikiran CornelisAnthonie van Peursen dan Catatan Reflektifnya. Yogyakarta: Pustaka Pelajar.

Endraswara, S. 2012. Metodologi Penelitian Kebudayaan. Yogyakarta: UGM Press.

Greetz, J. 1986. Mojokuto: Dinamika Sosial sebuah Kota di Jawa. Jakarta: Pustaka Grafitipress

Hadikusuma, H. 1990. Hukum Perkawinan Adat. Bandung: Citra Aditya Bakti.
Hamid, R. \& Madjid, S. 2011. Pengantar Ilmu Sejarah. Tamalanrea: Ombak.

Rendra. 1983. Mempertimbangkan Tradisi. Jakarta: Gramedia.

Soebadio, H, dkk. 1981. Adat-istiadat Nusa Tenggara Timur. Jakarta: Depertemen Pendidikan dan Kebudayaan

Soebadio, H, dkk. 1983. Adat dan Upacara Perkawinan daerah Nusa TenggaraTimur. Jakarta: Depertemen Pendidikan dan Kebudayaan.

Syamsuddin, H. 2007. Metodologi Sejarah. Bandung: Ombak.

Tamburaka, E. 1997. Pengantar Ilmu Sejarah. Kendari: Rineka Cipta.

Usfinit, A. 2003. Maubes Insana: Salah satu Masyarakat di Timor dengan Struktur Adat yang Unik. Kupang: Kanisius. 